\title{
Histological study of potassium 2-((4-amino-5-(morpholinomethyl)- 4H-1,2,4-triazole-3-yl)thio)acetate (PKR-173) corrective influence on the chickens liver state in the condition of tetracycline hepatitis
}

\author{
R. 0. Shcherbyna ${ }^{1}$, Ye. V. Vashchyk ${ }^{2}$ \\ ${ }^{1}$ Zaporizhzhia State Medical University, Ukraine, ${ }^{2}$ Sumy National Agrarian University, Ukraine
}

Key words: 1,2,4-triazole, hepatitis, histological techniques, tetracycline.

Zaporozhye medical journal 2018; 20 (3), 404-412

DOI:

$10.14739 / 2310-1210$

2018.3.130488

E-mail:

rscherbyna@gmail.com
Despite great scientific progress in the sphere of hepatoprotectors development during recent years, the issues of hepatocytes protection and regeneration is relevant enough. In this aspect derivatives of heterocyclic systems are of great interest, in particular, of 1,2,4-triazole.

The aim is histological study of the compound of potassium 2-((4-amino-5-(morpholinomethyl)-4H-1,2,4-triazol-3-yl)thio)acetate (PKR-173) corrective influence on the chickens liver under tetracycline hepatitis condition.

Materials and methods. As an object of research potassium 2-((4-amino-5- (morpholinomethyl)-4H-1,2,4-triazol-3-yl)thio) acetate was used which is a water-soluble compound. Histological examination was carried out of the intact chickens liver (intact control); of the chickens after tetracycline administration (control pathology); of the chickens which before the administration of tetracycline were administrated PKR-173 compound or thiotriazoline. All chickens were administrated tetracycline per os in the doze of $500 \mathrm{mg} / \mathrm{kg}$ for 5 days. PKR-173 compound and thiotriazoline were administrated per os for 3 days before tetracycline in doze of $150 \mathrm{mg} / \mathrm{kg}$ and $50 \mathrm{mg} / \mathrm{kg}$ respectively.

Results. It has been noted that preventive administration of PKR-173 compound for chickens aged 7-18 days visually prevented the development of nonspecific morphological changes which are characteristic of acute moderately severe drug-induced bird's liver injury. Compound PKR-173 contributed the organ histostructure normalization, prevented dystrophy manifestations, significantly reduced necrosis of hepatocytes and inflammatory reaction in the perivenular zone of triad system. Comparative drug thiotriazoline prevented hepatocytes dystrophy manifestation, in the vast majority of chickens contributed to hepatic plates structure restoration and inflammatory response reduction. In order to confirm the visual data according to the task, a semi-quantitative assessment of the PKR-173 and thiotriazoline corrective effect on chickens liver parenchyma morphological state was carried out.

Conclusions. Analysis of the pathological process quantitative characteristics, which developed in the chicken liver after tetracycline administration and corrective influence of the investigated drugs on it, has shown that the PKR-173 compound significantly reduced the manifestations of all the pathological features detected for testing compared to control pathology. The PKR-173 compound is probably not inferior to comparative drug thiotriazoline by normalizing effect on the organ histostructure restoration and antidystrophic action intensity. The PKR-173 compound significantly outperforms the comparative thiotriazoline for anti-necrotic and anti-inflammatory effects.
Киючові слова:

1,2,4-тріазол, гепатит, гістологічне АосліАження, тетрациклін.

Запорізький медичний журнал. - 2018. -

T. 20, № 3(108), C. 404-412
Гістологічне дослідження корегувального впливу сполуки калій 2-((4-аміно5-(морфолінометил)-4Н-1,2,4-тріазол-3-іл)тіо)ацетату (ПКР-173) на стан печінки курчат в умовах тетрацикиінового гепатиту

\section{Р. О. Щербина, Є. В. Ващик}

Незважаючи на великий науковий прогрес у галузі розробки гепатопротекторів, проблема захисту та регенерації гепатоцитів € актуальною. Інтерес у цьому аспекті викликають похідні гетероциклічних систем, а саме 1,2,4-тріазолу.

Мета роботи - гістологічне дослідження корегувального впливу сполуки калій 2-((4-аміно-5-(морфолінометил)-4Н-1,2,4-тріазол-3-іл)тіо)ацетат (ПКР-173) на стан печінки курчат в умовах тетрациклінового гепатиту.

Матеріали та методи. Об'єкт дослідження - калій 2-((4-аміно-5-(морфолінометил)-4Н-1,2,4-тріазол-3-іл)тіо)ацетат, що є водорозчинною сполукою. Виконали гістологічне дослідження печінки інтактних курчат (інтактний контроль); курчат, яким вводили тетрациклін (контрольна патологія); курчат, яким профрілактично разом із тетрацикліном вводили сполуку ПКР-173 або тіотріазолін. Тетрациклін всім курчатам вводили per os у дозі 500 мг/кг протягом 5 діб. Сполуку ПКР-173 і тіатріазолін вводили per os протягом 3 діб до тетрацикліну в дозі 150 мг/кг та 50 мг/кг відповідно.

Результати. Профілактичне введення сполуки ПКР-173 курчатам віком 7-18 діб візуально запобігає розвитку в печінці неспецифічних морфологічних змін, характерних для гострого помірно вираженого медикаментозного ураження. Сполука ПКР-173 сприяє нормалізації гістоструктури органа, запобігає проявам дистрофії, виразно знижує некроз гепатоцитів і запальну реакцію перивенулярно у системі тріад. Препарат порівняння тіотріазолін запобігає проявам дистрофії гепатоцитів, у більшості курчат сприяє відновленню балкового рисунка та зменшенню запальної реакції. Для підтвердження візуальних даних виконали напівкількісне (бальне) оцінювання коригувального впливу сполуки ПКР-173 та тіотріазоліну на морфологічний стан печінкової паренхіми курчат.

Висновки. Аналіз кількісних характеристик патологічного процесу, що розвинувся в печінці курчат після введення тетрацикліну, та коригувального впливу на нього досліджених засобів показав: сполука ПКР-173 вірогідно знижує прояви всіх визначених для тестування ознак патології порівняно з контролем. Сполука ПКР-173 вірогідно не поступається препарату порівняння тіотріазоліну за нормалізуючим впливом на відновлення гістоструктури органа, виразністю дії, що запобігає розвитку дистрофії. Сполука ПКР-173 вірогідно перевищує препарат порівняння тіотріазолін за антинекротичним і протизапальним впливом. 


\section{Гистологическое исследование корректирующего воздействия калий 2-((4-амино-5-(морфолинометил)-4Н-1,2,4-триазол-3-ил)тио)ацетата (ПКР-173) на состояние печени цыплят в условиях тетрацикиинового гепатита}

\section{Р. А. Щербина, Е. В. Ващик}

Несмотря на большой научный прогресс в области разработки гепатопротекторов, проблема защиты и регенерации гепатоцитов является весьма актуальной. Большую заинтересованность в данном аспекте вызывают производные гетероциклических систем, а именно 1,2,4-триазола.

Цель работы - гистологическое исследование корректирующего воздействия соединения калий 2-((4-амино-5-(морфолинометил)-4Н-1,2,4-триазол-3-ил)тио)ацетат (ПКР-173) на состояние печени цыплят в условиях тетрациклинового гепатита.

Материалы и методы. Объект исследования - калий 2-((4-амино-5-(морфолинометил)-4Н-1,2,4-триазол-3-ил)тио)ацетат, который является водорастворимым соединением. Проведено гистологическое исследование печени интактных цыплят (интактный контроль); цыплят, которым вводили тетрациклин (контрольная патология); цыплят, которым профилактически до тетрациклина вводили соединение ПКР-173 или тиотриазолин. Тетрациклин всем цыплятам вводили per os в дозе 500 мг/кг в течение 5 суток. Соединение ПКР-173 и тиотриазолин вводили per os в течение 3 суток до тетрациклина в дозе $150 \mathrm{mг} / к г$ и 50 мг/кг соответственно.

Результаты. Отмечено, что профилактическое введение соединения ПКР-173 цыплятам в возрасте 7-18 суток визуально препятствует развитию в печени птиц неспецисических морфологических изменений, характерных для острого умеренно выраженного медикаментозного поражения. Соединение ПКР-173 способствует нормализации гистоструктуры органа, препятствует проявлениям дистрофии, определенно снижает некроз гепатоцитов и воспалительную реакцию перивенулярно в системе триад. Препарат сравнения тиотриазолин препятствует проявлениям дистрофии гепатоцитов, у большинства цыплят способствует восстановлению балочного рисунка и снижению воспалительной реакции. Для подтверждения визуальных данных проведена полуколичественная (балльная) оценка корректирующего воздействия соединения ПКР-173 и тиотриазолина на морфологическое состояние печеночной паренхимы цыплят.

Выводы. Анализ количественных характеристик патологического процесса, развившегося в печени цыплят после введения тетрациклина, и корректирующего воздействия на него исследованных средств показал, что соединение ПКР-173 достоверно снижает проявления всех определенных для тестирования признаков патологии по сравнению с контрольной патологией. Соединение ПКР-173 достоверно не уступает препарату сравнения тиотриазолину по нормализующему влиянию на восстановление гистоструктуры органа, выразительности препятствующего развитию дистрофии действия. Соединение ПКР-173 достоверно опережает препарат сравнения тиотриазолин по антинекротическому и противовоспалительному воздействию.

\section{Introduction}

It is well-known that liver is one of the key organs, which participates virtually in all biochemical processes of the organism [1]. It is a natural filter in the organism which protects it not only from own metabolites but also from harmful medicines and chemicals [1]. This organ is essential in the processes concerned with growth and organism nutrients and energy supply and its combating different diseases, etc. [1].

Despite a great scientific progress in the sphere of hepatoprotectors development in recent years, the issues of hepatocytes protection and regeneration are still relevant nowadays [2]. In this aspect derivatives of heterocyclic systems are of great interest, in particular, of 1,2,4-triazole. Thus, derivatives of this heterocyclic system are actively investigated for their hepatoprotective qualities revealing [3-5]. That is why, taking the above mentioned into consideration, we thought it would be worthwhile to perform a histological examination of potassium 2-((4-amino-5-(morpholinomethyl)$4 \mathrm{H}-1,2,4-$ triazol-3-yl)thio)acetate influence on the chickens liver state in the condition of tetracycline hepatitis.

\section{The aim}

The aim was histological study of the compound of potassium 2-((4-amino-5-(morpholinomethyl)-4H-1,2,4-triazol-3-yl) thio)acetate (PKR-173) corrective influence on the chickens liver under tetracycline hepatitis condition.

\section{Material and methods}

Potassium 2-((4-amino-5-(morpholinomethyl)-4H-1,2,4triazole-yl-3)thio)acetate (PKR-173) (Fig. 1) was used as an object of research [6].

It was conducted liver histological study of the intact chickens (intact control), of the chickens after tetracycline administration (control pathology); of the chickens which before tetracycline were administrated PKR-173 compound or thiotriazolin. The study was conducted at the Central Scientific Research Laboratory (CSRL) of the National University of Pharmacology by the Senior Scientific Member Yu. B. Laryanovska, PhD (Biology), directed by O. Yu. Koshova, Head of CSRL, Senior Scientific Member, PhD (Pharmaceutical Sciences).

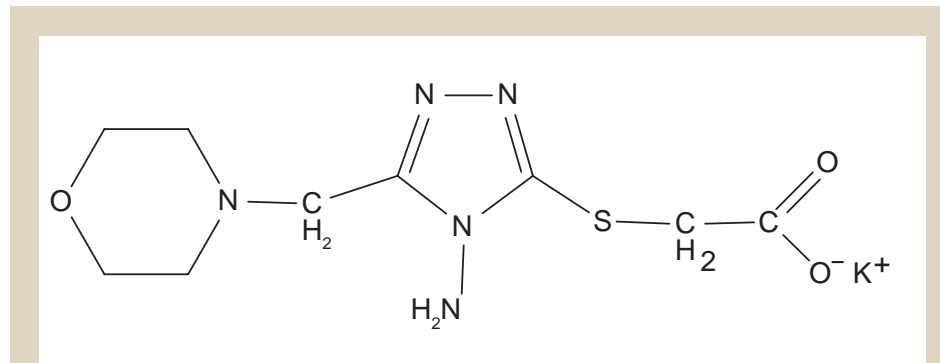

Fig. 1. Structural formula of potassium 2-((4-amino-5-(morpholinomethyl)-4H-1,2,4-triazole-yl-3) thio)acetate (PKR-173)
Ключевые слова: 1,2,4-триазол, гепатит, гистологическое исследование, тетрациклин.

Запорожский медицинский журнал. - 2018. -

T. 20, № 3(108). C. 404-412 
All chickens were administrated tetracycline per os in the dose of $500 \mathrm{mg} / \mathrm{kg}$ for 5 days. PKR-173 compound and thiotriazoline were administrated per os for 3 days before tetracycline in doze of $150 \mathrm{mg} / \mathrm{kg}$ and $50 \mathrm{mg} / \mathrm{kg}$, respectively [7].

Selection of the chickens' samples for each experimental group was performed on the $12^{\text {th }}$ day from the experiment beginning. The material was fixed in $10 \%$ of formalin, then subjected to graded alcohols for dehydration, and then embedded in paraffin wax. Paraffin blocks were cut into 4-5 $\mu \mathrm{m}$-thick sections with a luge microtome MC 2. The tissue slices were then stained with hematoxylin (acid Mayer's solution) and eosin for microscopic examination [8], which was performed with the help of Granum microscope. Microphotographing of images was done by means of digital video-camera Granum DSM 310. Photos were processed on computer Pentium 2,4GHz with the help of Toup View program.

For more convenient comparison and more objective picture of the obtained results a semi-quantitative estimation of liver damage degree of chickens different groups was performed on the stained with haematoxylin and eosin micropreparations. Among the assessed factors were the followings: hepatocytes dystrophy degree, presence and lesion site of hepatic plates structure damage, cells necrosis and inflammatory reaction. Semi-quantitative visual examination of the histo-chemical reactions intensity by Sokolovsky method was taken as the basis [9]. Each type of damage was estimated separately.

Disperse analysis (Kruskal-Wallis criterion) was applied for statistic results obtaining in the course of samples comparison - the criterion of Mann-Whitney at the $p$ value of $\leq 0,05$ was considered statistically significant [10-12]. The program Statistica 6.0 was used for statistical processing.

\section{Results and discussion}

According to the results of light optical examination the liver histostructure of intact chickens conformed to healthy organ and was specific to this age period [13,14]. Liver lobulation was not obvious. Fibrous tissue between hepatic lobules was not formed. The lobules were defined by portal triad spaces - portal tracts (zones of liver artery, portal vein and bile duct branches). The zones of triads were quite narrow. Liver lobules parenchyma consisted of liver layers, each of them was formed by several polygonal form hepatocytes with somewhat rounded edges, visible cells contours and sharply defined centrally placed nucleus (mainly 1 per cell), in which nuclei and granules of chromatin were clearly visualized. Cytoplasm of hepatocytes was evenly stained, did not contain any inclusions at the visual light-optical level. Radial direction of liver plates was the most obvious near the central veins; at the distance the plates had round shape. Between the liver plates there were sinusoid hemocapillaries, in which there were a limited number of lymphoid cells and nuclear erythrocytes. Central and interlobular veins, vessels of triads generally were not expanded, not filled with blood, Kupffer cells were without specific features (Fig. 2). Part of the chickens had lymphocyte aggregations of different sizes near some interlobular veins. Central vein of lymphoid tissue wasn't observed in organ parenchyma near liver triads veins.

After tetracycline administration in the chickens liver of the control pathology group the morphological picture was observed that is typical for many other liver diseases including drug-induced ones: dystrophic changes of hepatocytes, necrosis and inflammation. Dystrophic changes were presented by a rather common prevailing hydropic dystrophy and by sufficiently limited focal small-droplet fatty dystrophy. There was also unobvious granular dystrophy which had limited nature. In the zones of hydroid degeneration the structure of liver plates was often violated,
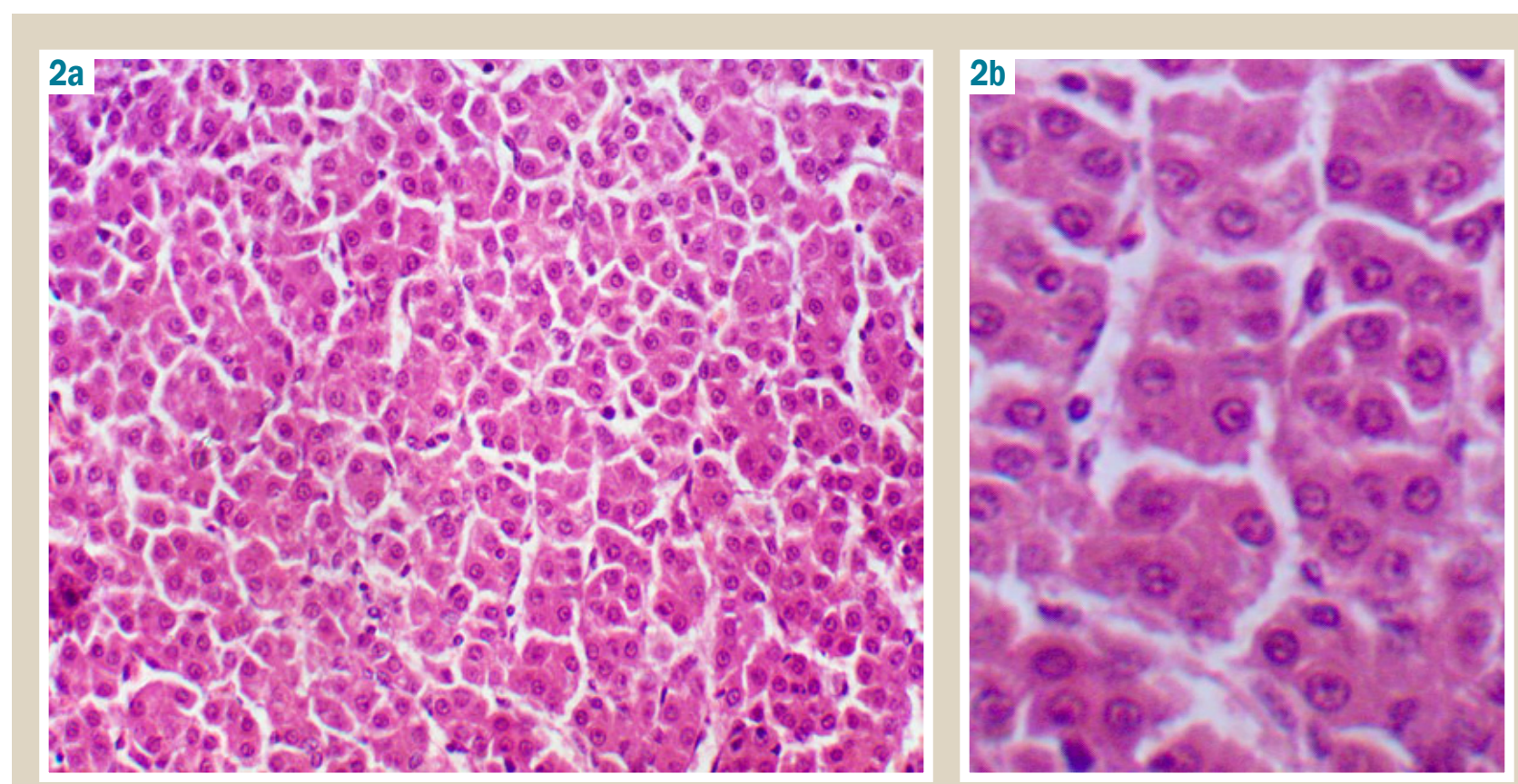

Fig. 2. Intact chicken liver fragment (a: $\times 200, b: \times 400)$ : the structure of liver plates is well-defined, hepatocytes with evenly painted cytoplasm, normal nuclei and moderately dilated sinusoidal hemocapillaries. Hematoxylin-eosin staining. 
hepatocytes as well as nuclei had different size, quite often the cells lysis was obvious (Fig. 3, 4, 5).

In different loci of liver parts there were coagulative and colliquative centers of hepatocytes necrosis. They were massively infiltrated with lymphoid-histiocytic-macrophagal elements, which substituted the dead cells. Necrotic foci often looked like «thimble», but sometimes infiltrating cells penetrated between the hepatic plates in the lobule. In several loci of necrosis among infiltrative cells there were groups of "buried" hepatocytes (Fig. 6).

Inflammatory changes were limited mainly to portal areas. They were quite expressive (Fig. 8).

The unequal dilation of blood-filled sinusoidal hemocapillaries was observed, especially in subcapsular zone, there was swelling of Disse spaces, in some loci of liver lobules the veins were filled with blood or blood clots (Fig. 9).

Therefore, tetracycline administration per os in the doze of $500 \mathrm{mg} / \mathrm{kg}$ for 5 days in the control pathology group caused non-specific type of morphological changes, which are typical for other drug-induced related chickens liver damage [15].

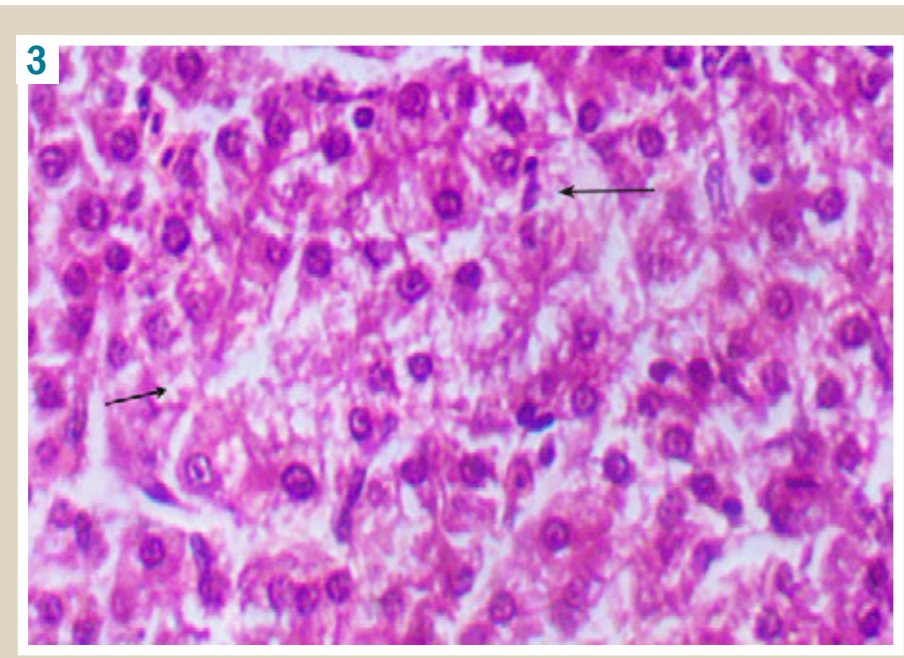

Fig. 3. Chicken liver fragment after tetracycline administration $(\times 400)$. Violation of the plates pattern hydroid degeneration of hepatocytes, lysis of cells. Hematoxylin-eosin staining.

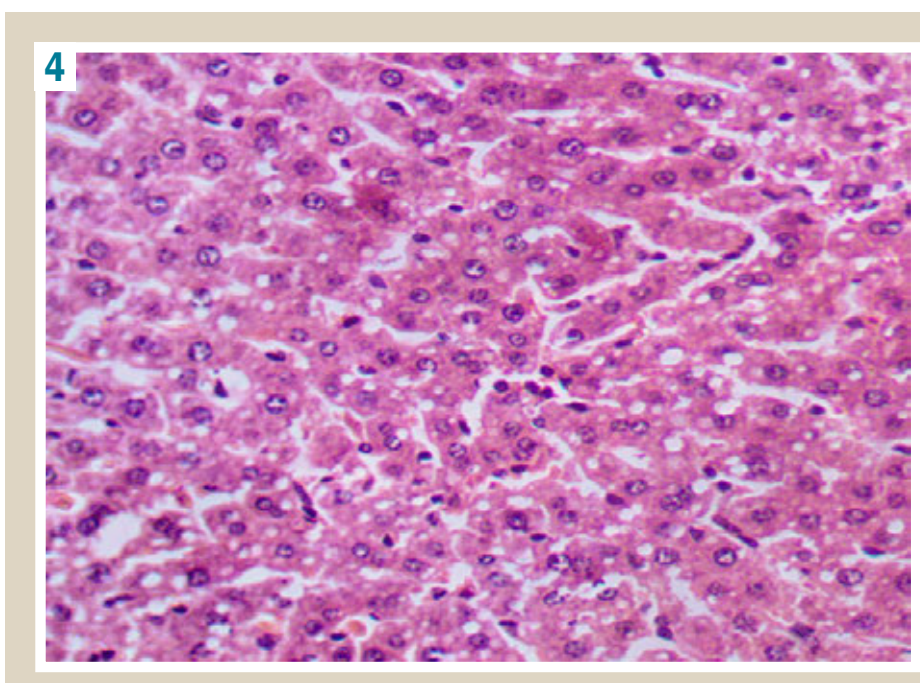

Fig. 4. Chicken liver fragment after tetracycline administration (×250). Fatty liver dystrophy. Hematoxylin-eosin staining.

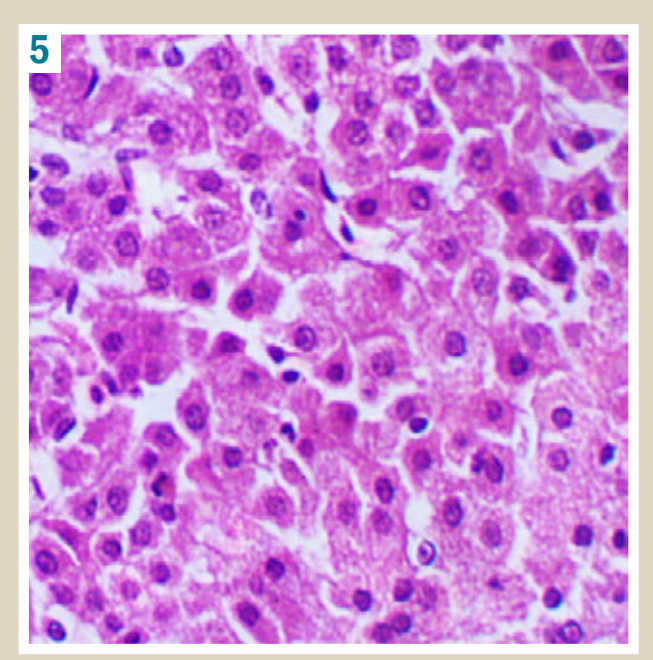

Fig. 5. Chicken liver fragment after tetracycline administration $(\times 400)$ Granular dystrophy of hepatocytes. Hematoxylin-eosin staining.
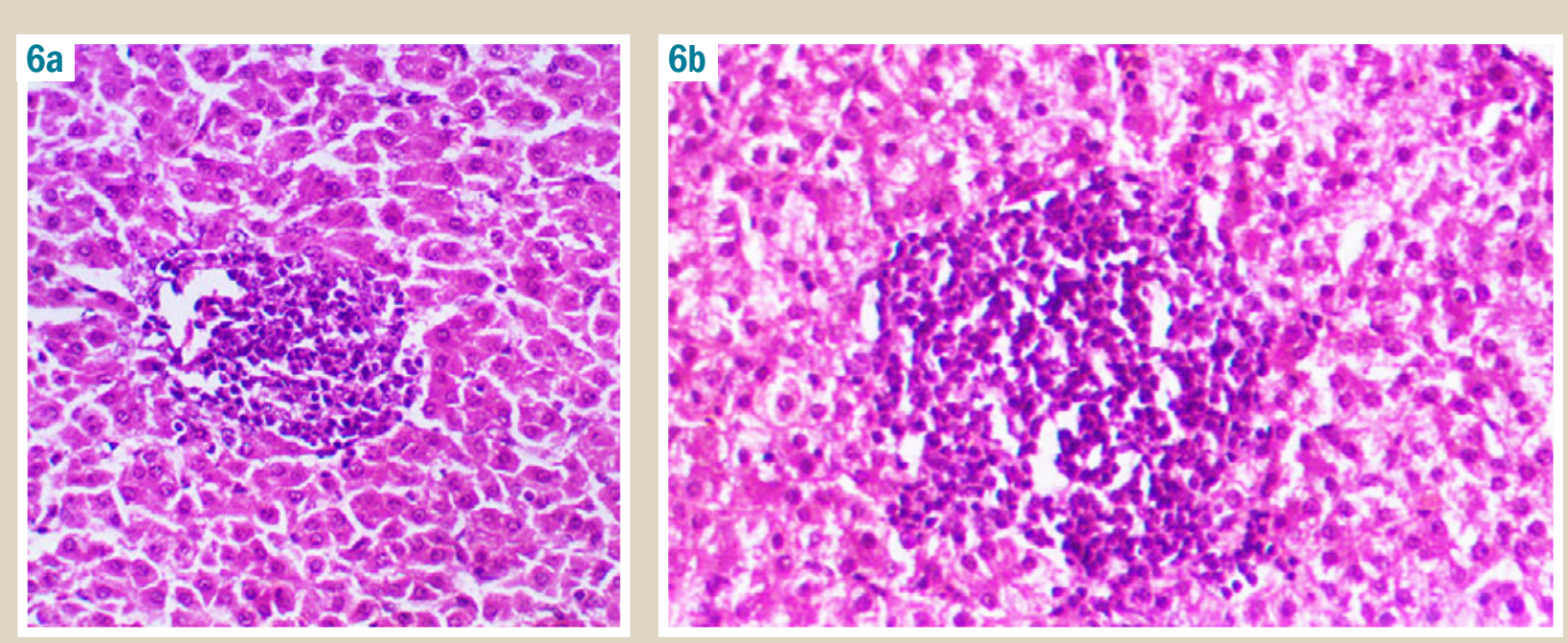

Fig. 6. Chicken liver fragment after tetracycline administration ( $\times 200)$. Focus of colliquative necrosis, round cell infiltration (a-b). Infiltration of lobule (b). Hematoxylin-eosin staining 
After the PKR-173 compound administration for prophylactic purpose before tetracycline there was pronounced decrease of hydroid degeneration in all chickens liver, while fatty degeneration of hepatocytes was absent. The structure of liver plates was fully restored (Fig. 10). Granular cell dystrophy remained in restricted loci of several lobules (Fig. 11).

In some cases there were small single loci of colliquative necrosis. In the group as a whole there was decrease of hepatocytes coagulative necrosis (Fig. 12). As for inflammation reaction in the zones of portal tracts, the level of their expression varied in different chickens (Fig. 13).

Moderate proliferation of ductular epithelium was visible in some cases (Fig. 14a, b).

Thiotriazoline administration as the comparison drug had a definite positive effect on the liver parenchyma morphological state of most chickens (80\%). The birds did not have hydropic and fatty degeneration of hepatocytes, but there was moderate granular cell dystrophy. The plates pattern was generally restored, but hepatocytes were somewhat swollen, sinusoidal capillaries were often clearly dilated, which somewhat obscured the picture clarity (Fig. 15).

Almost all these chickens had traceable local small foci of colliquative and coagulative necrosis with abundant lymphoid-macrophagal infiltration (Fig. 15, Fig. 16).

However, none of these chickens had an inflammatory reaction.

Unlike the vast majority of cases, one chicken of this group showed complete parenchyma melting with neutrophilic infiltration of detritus in a significant portion of the liver micrpreparation sample (Fig. 17).

In other parts of this micropreparate sample massive necrosis of lobules agglomerates with abundant lymphoid cells infiltration, which replaced hepatocytes, was observed (Fig. 18).

Consequently, the prophylactic administration of PKR173 compound to chickens aged $7-18$ days visually prevented from non-specific morphological changes development in the birds' liver, which was characteristic for acute moderate lesions. The PKR-173 compound promoted the organ his-
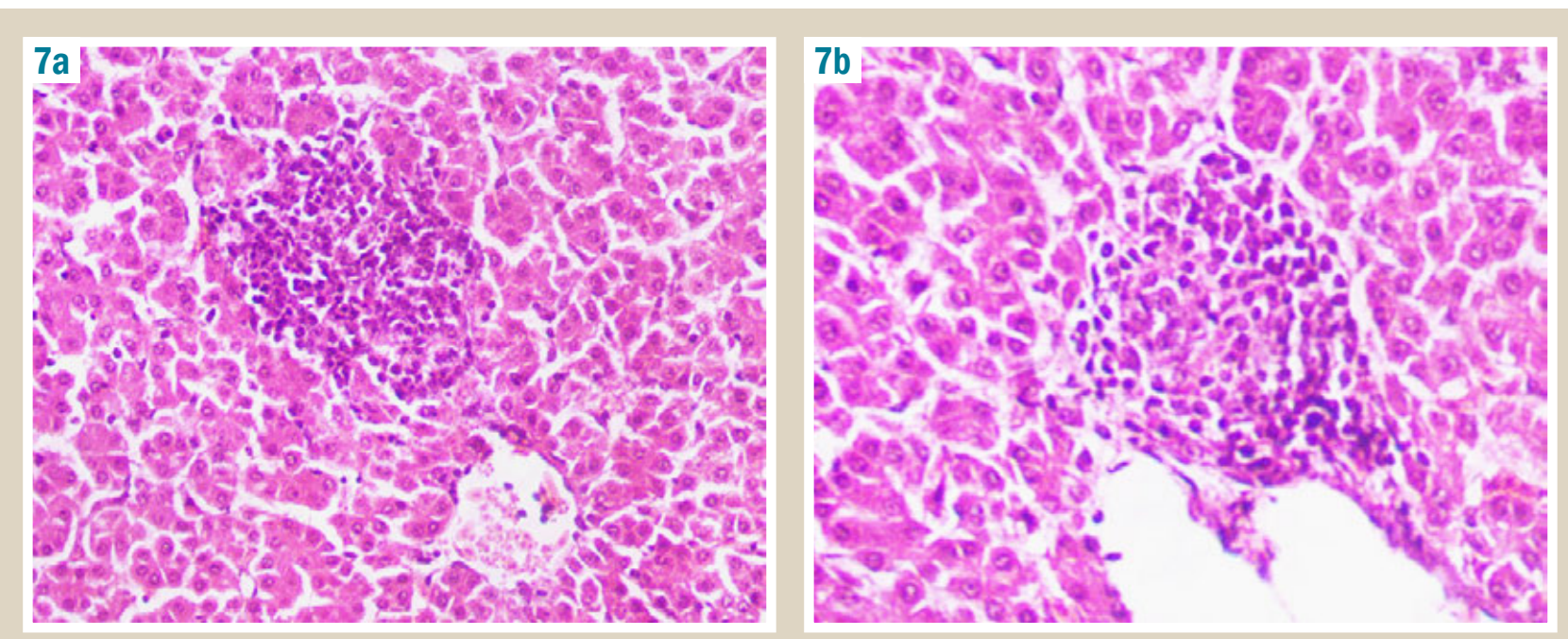

Fig. 7. Chicken liver fragment after tetracycline administration $(\times 200, \times 250)$. Foci of coagulative necrosis, lymphoid-macrophagal infiltration (a-b). In several infiltrative cells there were hepatocytes elements. Hematoxylin-eosin staining.
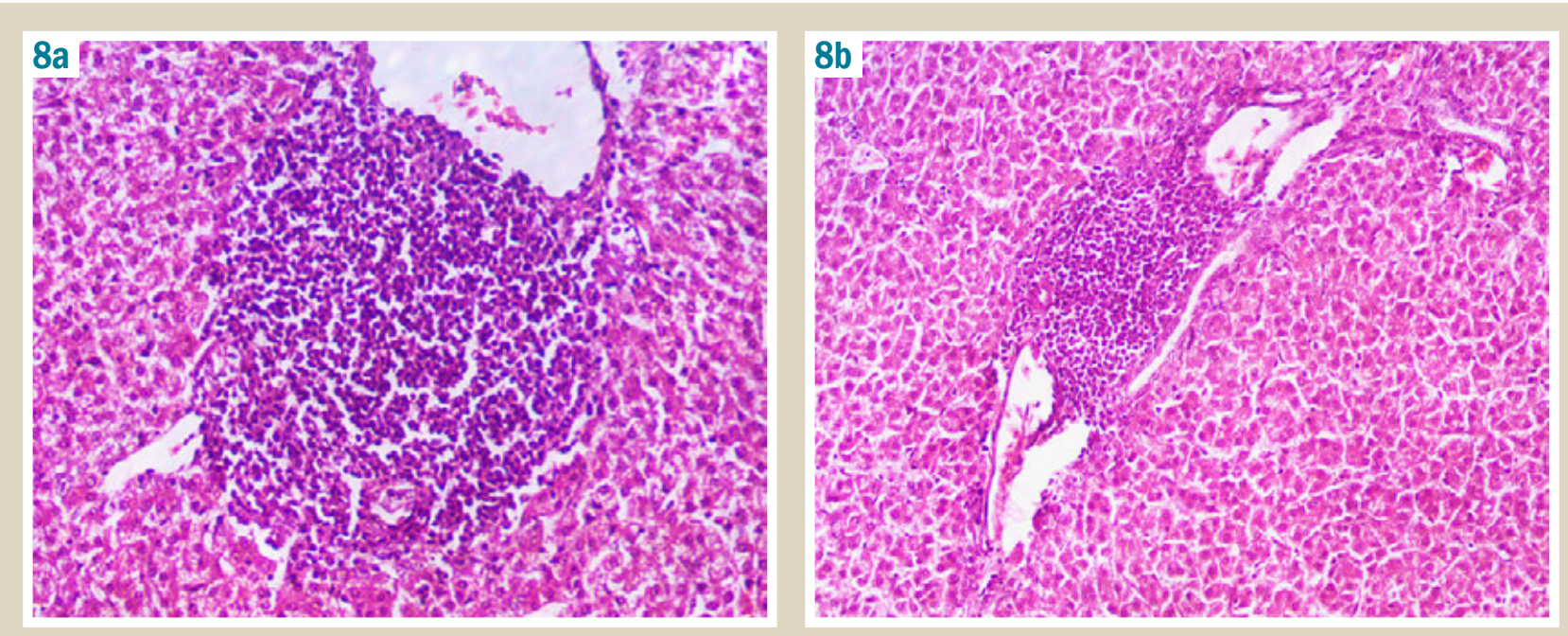

Fig. 8. Chicken liver fragment after tetracycline administration $(\times 200)$. Expressive inflammatory reaction in a portal zone. Hematoxylin-eosin staining. 


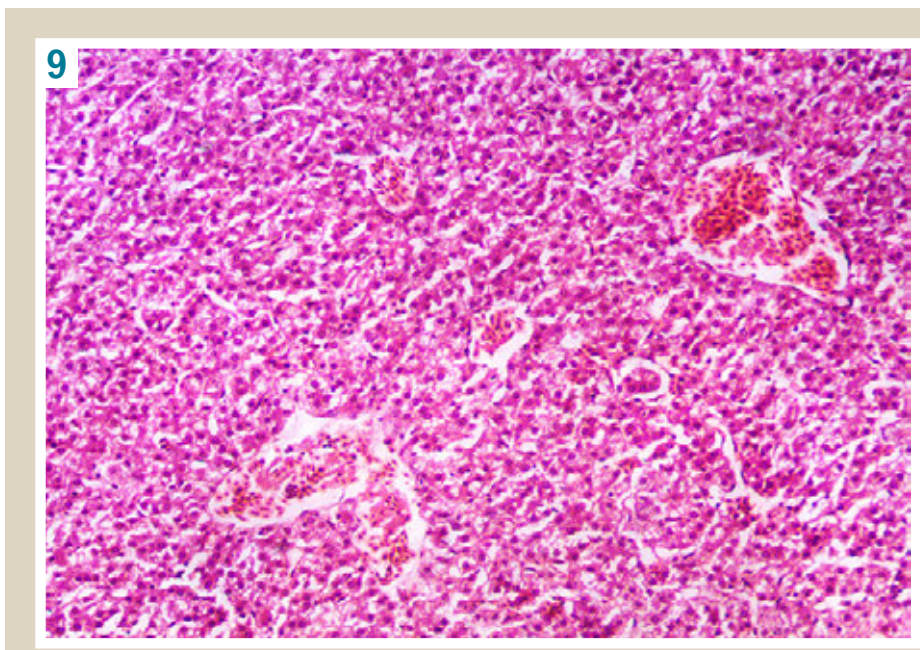

Fig. 9. Chicken liver fragment after tetracycline administration $(\times 200)$. Thrombosis of venous vessels. Hematoxylin-eosin staining.

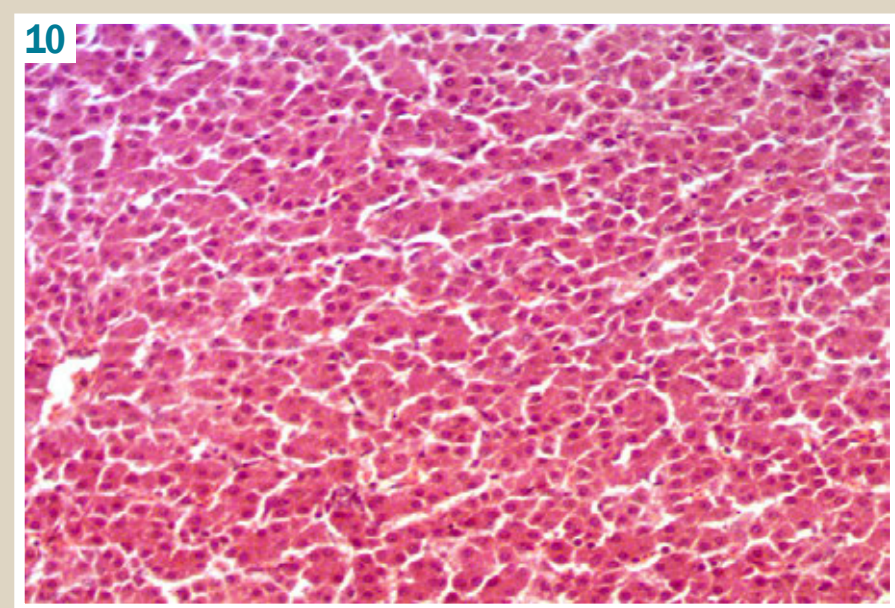

Fig. 10. Chicken liver fragment after the PKR-173 compound administration for prophylactic purpose before tetracycline $(\times 200)$. Liver plates structure restoration, absence of hepatocytes dystrophy. Hematoxylin-eosin staining.

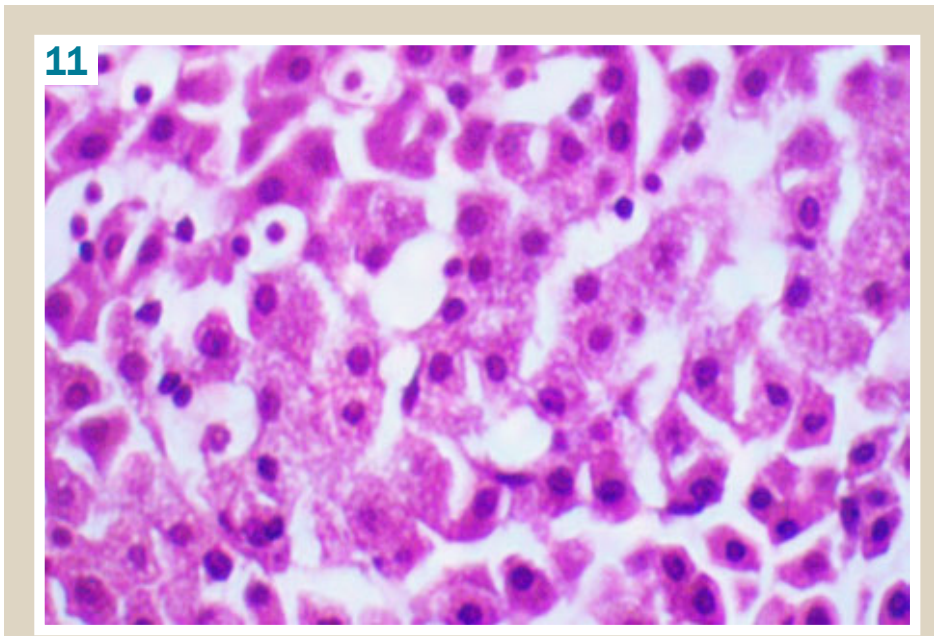

Fig. 11. Chicken liver fragment after the PKR-173 compound administration for prophylactic purpose before tetracycline (×400). Granular dystrophy of hepatocytes. Hematoxylin-eosin staining. tostructure normalization, prevented from dystrophy manifestations, significantly reduced hepatocytes necrosis and inflammatory reaction around the veins in the triad system.

Comparative drug thiotriazoline prevented hepatocytes dystrophy, in the vast majority of chickens it helped to restore the hepatic plates structure and reduce the inflammatory response.

In order to confirm the visual data, in accordance with the task, a semi-quantitative (ball) assessment of the PKR-173 compound and thiotriazoline corrective effects on the chickens hepatic parenchyma morphological state was carried out. The score points are given in the Table 1.
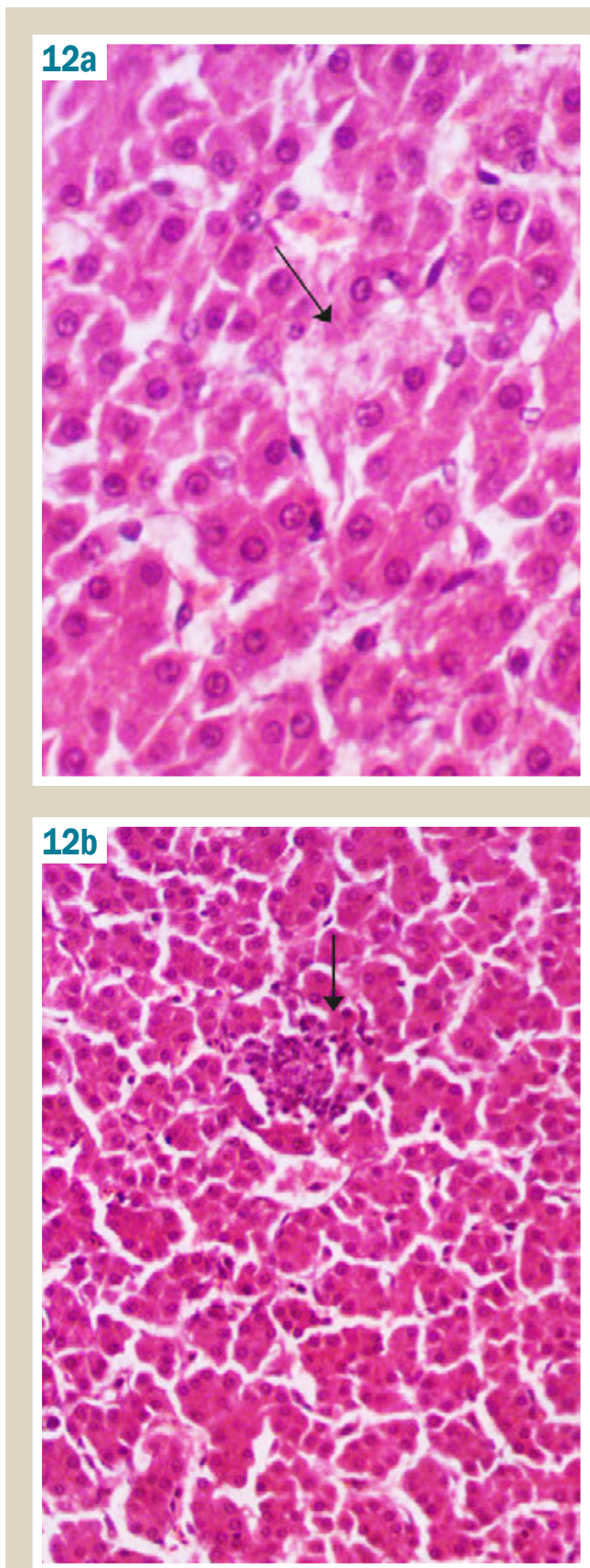

Fig. 12. Chicken liver fragment after the PKR-173 compound administration for prophylactic purpose before tetracycline. Small colliquative loci (a: $\times 250$ ) and small foci of coagulative (b: $\times 200)$ necrosis of hepatocytes. Hematoxylin-eosin staining. 

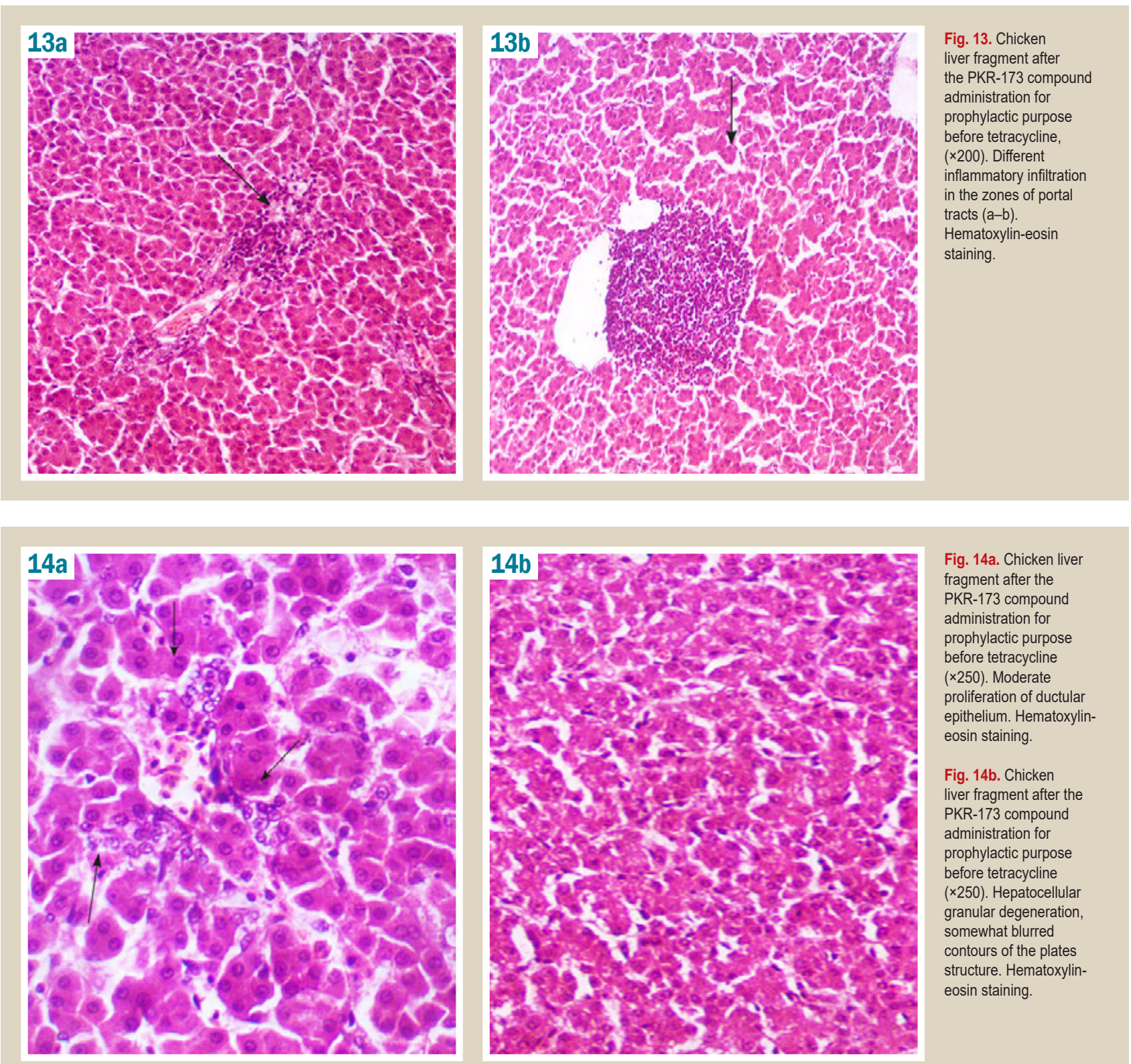

Fig. 14a. Chicken liver fragment after the PKR-173 compound administration for prophylactic purpose before tetracycline (×250). Moderate proliferation of ductular epithelium. Hematoxylineosin staining.

Fig. 14b. Chicken liver fragment after the PKR-173 compound administration for prophylactic purpose before tetracycline (×250). Hepatocellular granular degeneration, somewhat blurred contours of the plates structure. Hematoxylineosin staining.
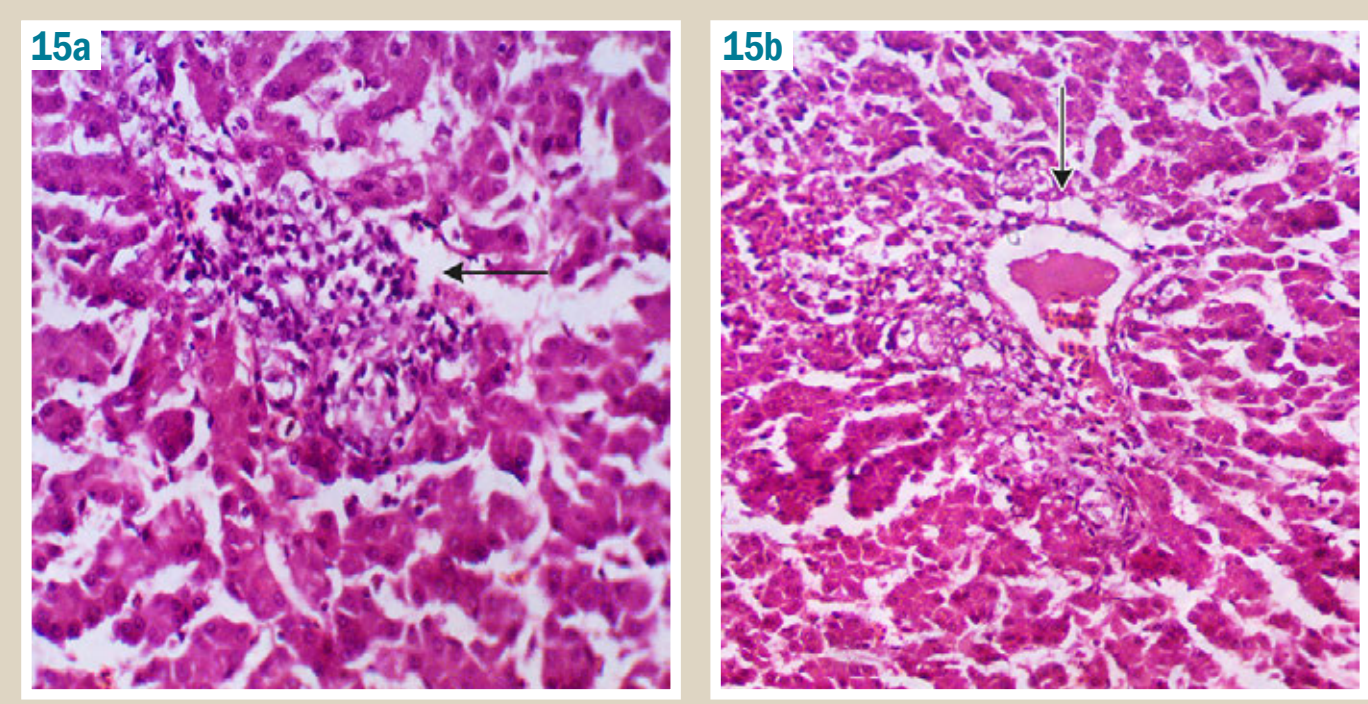

Fig.15. Chicken

liver fragment after thiotriazoline prophylactic administration before tetracycline administration $(\times 200)$. Periportal foci of hepatocytes colliquative necrosis with perifocal infiltration (a-b). Hematoxylin-eosin staining. 

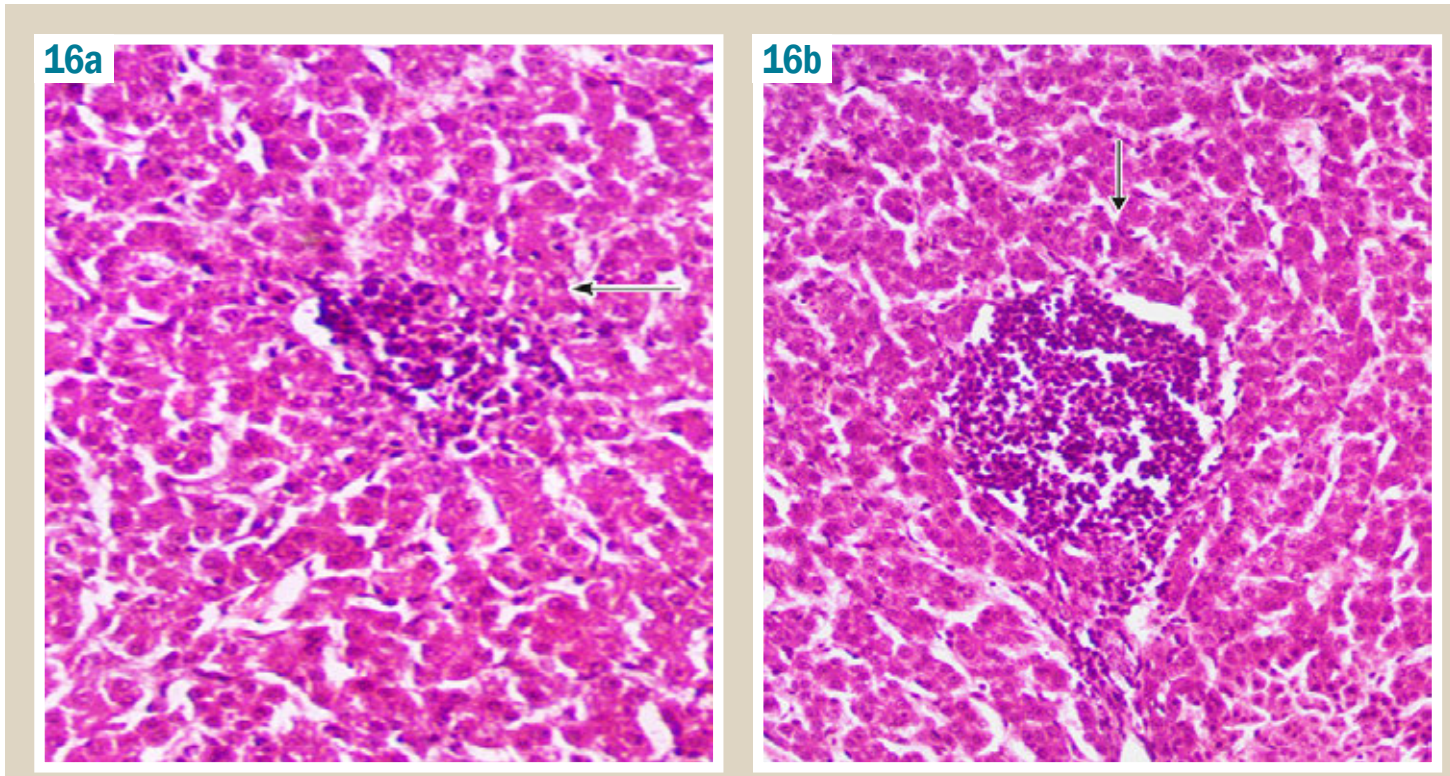

Fig.16. Chicken liver fragment after thiotriazolin prophylactic administration

before tetracycline administration $(\times 200)$. Focuses on different sizes coagulative necrosis in the lobules (a-b). Hematoxylineosin staining.
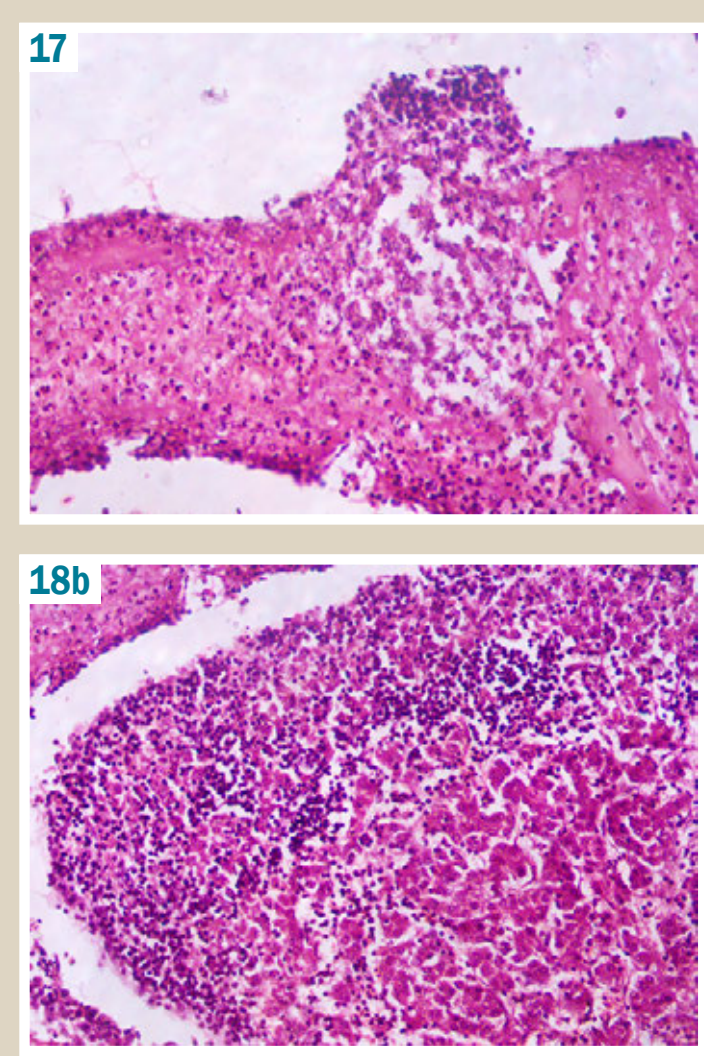
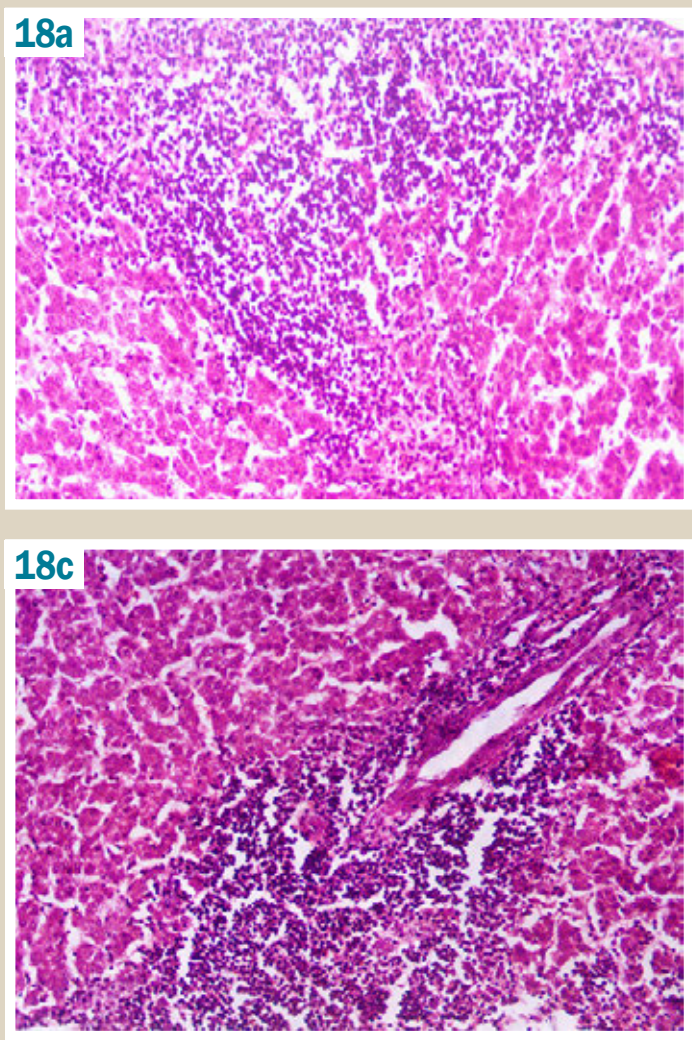

Fig. 17. Chicken liver fragment after thiotriazoline prophylactic administration before tetracycline administration (×200). Total melting of parenchyma lobules, neutrophilic infiltration of detritus. Hematoxylin-eosin staining.

Fig. 18. Chicken liver fragment after thiotriazoline prophylactic administration before tetracycline administration $(\times 100)$. Massive necrosis with lymphoid cells infiltrates in different zones of the micropreparate. Hematoxylin-eosin staining.

Table 1. Semi-quantitative assessment of the PKR-173 and thiotriazoline corrective effects on the chicken liver (points), Me (LQ; UQ)

\begin{tabular}{|c|c|c|c|c|}
\hline \multirow[t]{2}{*}{ Experimental groups } & \multicolumn{4}{|l|}{ Signs, points (medium) } \\
\hline & Expression of hepatocyte dystrophy & Necrotic changes of hepatocytes & Violation of the plates structure & Inflammatory reaction \\
\hline Intact control & $0(0 ; 0)$ & $0(0 ; 0)$ & $0(0 ; 0)$ & $0,5(0 ; 2)$ \\
\hline Tetracycline (CP) & $2.8(2 ; 3)^{*}$ & $2.6(2 ; 3)^{*}$ & $2.2(1 ; 3)^{*}$ & $2.8(2 ; 3)^{*}$ \\
\hline Tetracycline + PKR-173 & $0.2(0 ; 1)^{\star \star}$ & $0.6(0 ; 1)^{\star *}$ & $0(0 ; 0)^{\star *}$ & $1.0(0 ; 3)^{\star \star}$ \\
\hline Tetracycline + thiotriazoline & $0.8(0 ; 1)^{* / * *}$ & $2.2(1 ; 4)^{*} / \#$ & $0.8(0 ; 4)$ & $0.8(0 ; 4)$ \\
\hline$P$ & 0.008 & 0.008 & 0.0028 & 0.0408 \\
\hline
\end{tabular}

p: is the level of statistical significance when comparing the samples using the Kruskal-Wallis criterion; *: the level of statistical significance when comparing experimental groups with the IR group using the Mann-Whitney criterion; **: the level of statistical significance when comparing the experimental groups with the CP group using the Mann-Whitney criterion; ": the level of statistical significance when comparing the experimental groups with the SCR group using the Mann-Whitney criterion. 


\section{Conclusions}

1. Analysis of quantitative characteristics of pathological process which developed in the liver of chickens after tetracycline administration and corrective influence of investigated drugs on it showed that the PKR-173 compound significantly reduced the occurrence of all defined pathological test signs comparing to control disease.

2. The PKR-173 compound is probably not inferior to comparative drug thiotriazoline by normalizing effect on the organ histostructure restoration and antidystrophic action intensity.

3. The compound PKR-173 was significantly better than the comparison drug thiotriazoline by anti-necrotic and anti-inflammatory effects.

Prospects for further research are the more detailed study of potassium 2-((4-amino-5-(morpholinomethyl)-4H1,2,4-triazol-3-yl)thio)acetate on the ability to have hepatoprotective effect on various models of hepatitis.

Conflicts of Interest: authors have no conflict of interest to declare. Конфлікт інтересів: віАсутній.

Information about authors:

Shcherbyna R. O., MD, PhD, Associate Professor

of the Department of Toxicology and Inorganic Chemistry,

Zaporizhzhia State Medical University, Ukraine.

Vashchyk Ye. V., PhD, Associate Professor, Department of Veterinary Sanitary Examination, Microbiology and Zoohygiene Safety and Quality of Animal Products, Sumy National Agrarian University, Ukraine.

\section{Відомості про авторів:}

Щербина Р. О., канА. фарм. наук, Аоцент каф. токсикологічної та неорганічної хімії, Запорізький державний медичний університет, Україна.

Ващик Є. В., канд. вет. наук, Аоцент, Аокторант каф. ветсанекспертизи, мікробіології, зоогігієни та безпеки та якості продуктів тваринництва, Сумський національний аграрний університет, Україна.

\section{Сведения об авторах}

\section{Щербина Р. А., канА. фарм. наук, Аоцент}

каф. токсикологической и неорганической химии, Запорожский государственный медицинский университет, Украина.

Ващик Е. В., канА. вет. наук, Аоцент, Аокторант

каф. ветсанэкспертизы, микробиологии, зоогигиены

и безопасности и качества продуктов животноводства,

Сумский национальный аграрный университет, Украина.

Надійшла Ао редакції / Received: 26.10.2017

Після Аоопрацювання / Revised: 14.11.2017

Прийнято Ао Аруку / Accepted: 04.12.2017

\section{References}

[1] Xiao, S. (2014). Liver Pathology. Demos Medical Publishing.

[2] World Health Organization (2017): Russian. Retrieved from http://www. who.int/mediacentre/news/releases/2017/global-hepatitis-report/ru/.

[3] Danilchenko, D. M., Zvenigorodska, T. V., \& Parchenko, V. V. (2017) Natrii 2-(4-amino-(5-(furan-2-il)-1,2,4-triazol-3-iltio)atsetat, syntez, doslidzhennia biokhimichnykh pokaznykiv syrovatky krovi koriv pry yoho vykorystanni [Sodium 2-(4-amino-(5-(furan-2-yl)-1,2,4-triazole-3-ylthio) acetate, synthesis, the study of its biochemical indicators of blood serum in cows]. Current issues in pharmacy and medicine: science and practice, 10, 1(23), 76-80. [in Ukrainian]. doi: 10.14739/24092932.2017.1.93446.

[4] Bilay, I. M., Mihayluk, E. O., Parchenko, V. V., Kaplaushenko, A. G., Panasenko, A. I., \& Knysh, E. G. (2014). Doslidzhennia hepatoprotektornoi aktyvnosti pry eksperymentalnomu hepatyti pid vplyvom pokhidnykh 1,2,4-triazolu [The research of hepatoprotective activity in experimental hepatitis infl uenced by 1,2,4-triazole derivatives]. Current issues in pharmacy and medicine: science and practice, 2(15), 57-59. [in Ukrainian]. doi: https://doi.org/10.14739/2409-2932.2014.2.26165.

[5] Belay, I. M., Mikhaylyuk, E. O., Parchenko, V. V., Panasenko, A. I., \& Knysh, E. G. (2014). Vliyanie 4-amino-5-(furan-2-il)-4H-1,2,4-triazol-3tiola na pokazateli gepatoprotektornoj aktivnosti pri alkogol'nom gepatite u krys [Influence of 4-amino-5- (furan-2-il)-4H-1,2,4-triazol-3-thyol on the indicators of hepatoprotective activity in alcohol hepatitis in rats]. Vestnik Vitebskogo gosudarstvennogo medicinskogo universiteta, 13(2), 132-137 [in Russian]

[6] Shcherbyna, R. O. (2017). Syntez i fizyko-khimichni vlastyvosti v riadu solei 2-((4-R-3-(morfolinometylen)-4H-1,2,4-triazol-5-il)tio)atsetatnykh kyslot [Synthesis, physical and chemical properties of 2-((4-R-3-(morfolinomethylen)-4H-1,2,4-triazole-5-yl)thio)acetic acid salts]. Current issues in pharmacy and medicine: science and practice, 10, 1(23), 4-8. [in Ukrainian]. doi: 10.14739/2409-2932.2017.1.93424.

[7] Stefanov, O. V. (Ed.) (2001) Doklinichni doslidzhenia likarskykh zakhodiv [Preclinic investigation medicines]. Kyiv: Avitsena. [in Ukrainian]

[8] Merkulov, G. A. (1969). Kurs patologogistologicheskoj tekhniki [Course of pathological histology]. Moscow: Medicina. [in Russian].

[9] Sokolovskij, V. V. (1971). Gistokhimicheskiye issledovaniya v toksikologii [Histochemical studies in toxicology]. Saint Petersburg: Medicina. [in Russian].

[10] Khalafyan, A. A. (2007) Statistica 6. Statisticheskij analiz dannykh [Statistica 6. Statistical analysis of data]. Moscow: Binom-Press. [in Russian].

[11] Lapach, S. N., Chubenko, A. V., \& Babych, P. N. (2001). Statisticheskie metody $v$ mediko-biologicheskikh issledovaniyakh s ispol'zovaniem Excel [Statistical methods in biomedical research using Excel]. Kyiv: Morion. [in Russian].

[12] Rebrova, O. Yu. (2002) Statisticheskij analiz medicinskikh dannykh Primenenie paketa prikladnykh programm STATISTICA [Statistical analysis of medical data. Application of the STATISTICA software package]. Moscow: MediaSfera. [in Russian].

[13] Kol'berg, N. A., Buzanov, A. D., \& Valishyi, R. R. (2010). Morfologicheskie izmeneniya $v$ pecheni pticy pri ispol'zovanii antigomotoksicheskoj terapii [Morphological changes in poultry liver using antihomotoxic therapy]. Agrarnyj vestnik Urala, 1(67). [in Russian].

[14] Khamitova, L. Ye. (2015) Social'nyj analiz morfofunkcional'nykh pokazatelej pecheni golubej $i$ kur-brojlerov $v$ kritichnykh periodakh ontogeneza (Dis... kand. biol. nauk). [Comparative analysis of morphofunctional indicators of the liver of doves and broilers in the critical periods of ontogenesis. Dr. biol. sci. diss.]. Omsk. [in Russian].

[15] Serov, V. V., \& Lapysh, K. (1989). Morfologicheskaya diagnostika zabolevanij pecheni [Morphological diagnostics of liver diseases]. Moscow: Medicina. [in Russian]. 